\title{
A Leader in Institutional Design? Europe and the Governance of Trade and Monetary Relations
}

Vinod K. Aggarwal and Cédric Dupont*

\section{Introduction}

In many respects, Europe has been an innovator in the design of international institutions. In trade, Britain led with nineteenth-century unilateral trade liberalization, followed by the Cobden-Chevallier network of bilateral treaties, a customs union in central Europe, and then inward-looking arrangements with colonies. ${ }^{1}$ In the post-Second World War period, Europe has been moving toward regional political and economic integration since the 1950s. The European Community (EC) has also been a leader in the move toward transregional arrangements linking developing countries (Lomé Agreement) and Eastern European countries to the $\mathrm{EC}$ as well as inter-regionalism that brings it together with the Association of South East Asian Nations (ASEAN), Mercosur, and other regional blocs. ${ }^{2}$ In finance, Europeans were the primary architects of the gold standard in the nineteenth century, and adapted this system at the turn of the twentieth century. European states played crucial roles in the failed effort to revive the global economy through the innovation of monetary arrangements and the more successful efforts in creating the Bretton Woods system. In the post-Second World War period, following a bewildering array of monetary arrangements, most EC countries have relinquished their national currencies, leading to an unprecedented form of monetary union based on a single currency.

These European designs, for better or worse, have been mimicked throughout the world. The United States pursued bilateral treaties under the Reciprocal Trade Agreements Act in the 1930s, and groups of countries throughout Latin America 
and Africa pursued regional integration efforts (unsuccessfully, for the most part) in the 1960s. European success in integration has revived many oncemoribund regional agreements, and led to new accords in Africa, the Middle East, South Asia, North America, and Latin America. More recently, a growing web of bilateral free trade agreements has continued to link various national economies, including both the geographically propinquous and the more distant. The newest form of trade arrangements link regions together as with the Asia Pacific Economic Cooperation (APEC) forum and the proposed Free Trade Area of the Americas (FTAA).

In money, the Gold Standard has served as a puzzling benchmark for those seeking to achieve exchange rate stability under capital mobility. Currency boards, recently in vogue, are in some sense the modern form for those in the periphery who wish to emulate the strict commitment to gold in the nineteenth century. Although the various schemes designed by EC countries have so far had little impact, the dire consequences of recent financial crises and the successful implementation of monetary union may well provide new impetus for imitation. Whether this proves to be a step forward depends on the degree to which countries are able to pursue the necessary stages of economic liberalization as well as political and monetary cooperation that have accompanied the creation of the euro.

What do these new forms of institutional design portend for the global trade and monetary systems? In trade, will transregionalism or some type of interregionalism be the wave of the future, and will others imitate this form of managing trade? Will such arrangements undermine other, newer forms of trade arrangements such as bilateralism? Will these new forms of trade damage the World Trade Organization (WTO) or lead to further liberalization at the multilateral level? In money, how will the 'Euroized' Europe - in some respect now closer to the periphery - relate to a dollarized world? If the euro is successful, will other groupings imitate European monetary union? And if others follow, how will the current IMF-based system of floating exchange rates be affected by new fixed forms of regionally-based monetary coordination?

This paper examines the pattern of European institutional innovation and its likely consequences for both Europe and other states. Based on a general analytical framework for the evolution of governance structures in trade and money, we provide both conceptual advances and empirical evidence for Europe's role at the international level. Section II of the paper develops a classificatory framework to categorize trade and monetary arrangements. Using this basic structure, Sections III and IV provide an analytical history of different institutional forms to which Europe has contributed in trade and money, respectively. We also examine how these new institutional forms have interacted and how their dynamics have affected the choices of other states and regions in 
the world. Finally, we conclude with some comments on the likely direction that these arrangements will take, both in Europe and elsewhere.

\section{Categorizing trade and monetary arrangements}

Over the last 50 years, states have utilized a host of measures to promote or control trade and monetary flows. In terms of the number of actors, these include unilateral, bilateral, minilateral and multilateral arrangements. In terms of issue coverage, the range has been either narrow or broad in scope in trade, and has involved varying degrees of fixity in money. In addition, some arrangements are geographically concentrated, or 'regional', while others link states across long distances. For simplicity, the following two tables and our discussion focuses only on three dimensions of bargaining approaches: (1) the number of states involved; (2) issue scope in trade and fixity in money; and (3) geographical range. For sake of presentation, we do not include other possible characteristics in the table such as timing, openness versus closure, or the like, but instead discuss these in our empirical analysis. The cases focus for the most part on actions that have been taken either by individual European states or by grouping of European states. We begin with a discussion of trade.

\section{II.1 Classifying trade arrangements}

Table 6.1 classifies the variety of trade agreements on the dimensions of product coverage, actors, and geographical propinquity and provides illustrative examples of each. In brief, the top row (cells 1-6) refer to different forms of sectoralism. Cell 1 includes such measures as the British Corn Laws, which were a forerunner to the unilateral and then bilateral removal of tariffs in the late 1800s. In cell 2, we have geographically concentrated agreements in specific products, such as the 1932 German-Finish treaty that gave Finland preferential treatment in butter imports that went against the most favoured nation clause. ${ }^{4}$ Cell 3 refers to bilateral agreements that are geographically dispersed, such as a treaty between the UK and Argentina in the 1930s calling for the purchase of specific products (Snyder 1940). On a more protectionist basis, recent examples include the 1980s Voluntary Export Restraints (VERs) negotiated by the United States and by the EC on a bilateral basis with the Japanese in autos. In cells 4 and 5, we have product-specific sectoral agreements, with the first of these being geographically concentrated that focus on only a few products. An example in cell (4) is the 1951 European Coal and Steel Community (ECSC), which, while an agreement to liberalize trade, violated Article 24 of the GATT. This article permits the creation of free trade agreements and customs unions - but only a broad product basis rather than only in a few sectors. Cell 5 provides an example of dispersed sectoral minilateralism, as in the case of the Lancashire Agreement that 'managed' trade in cotton textile and apparel products in the 1950s between 

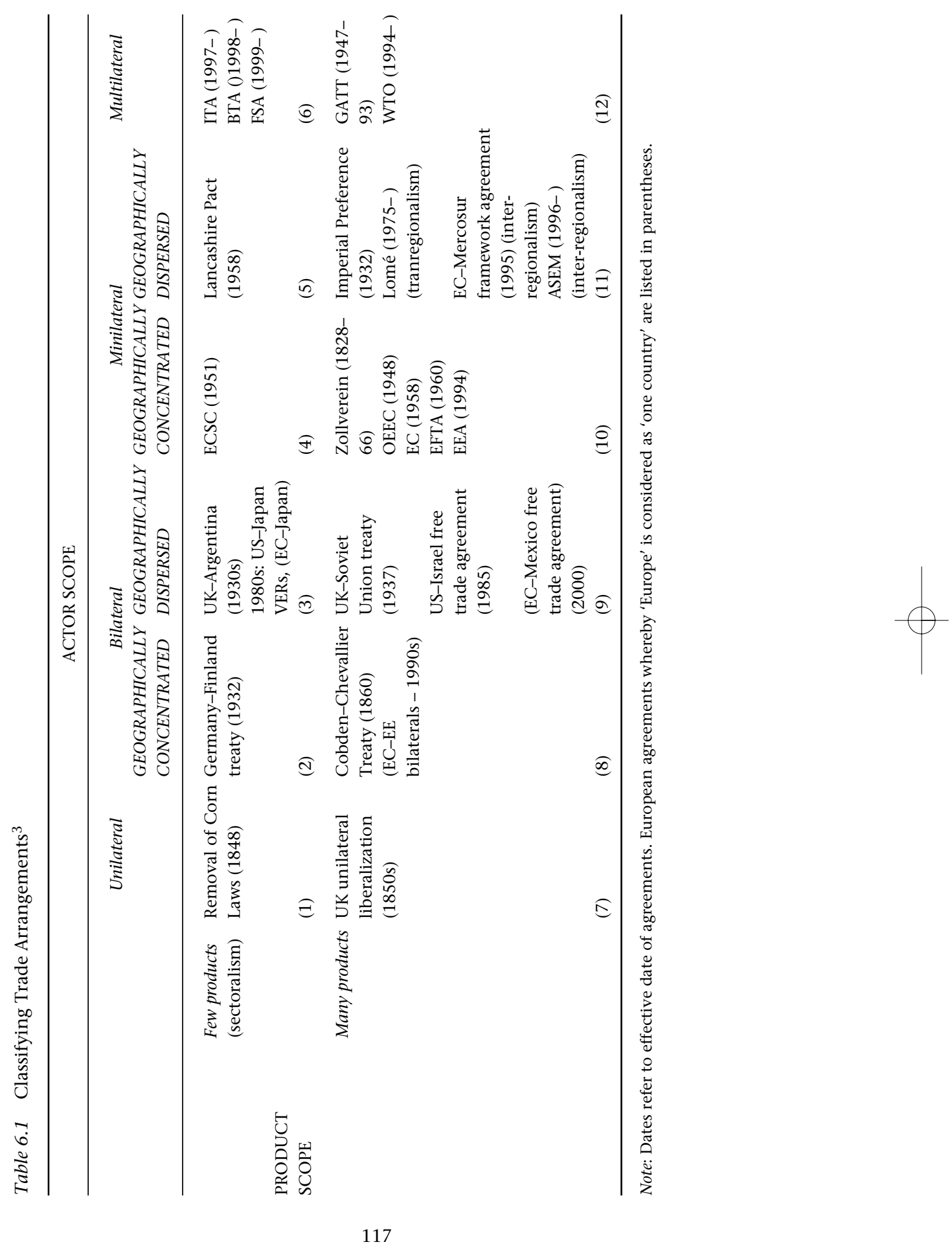
the UK and India, Pakistan, and Hong Kong. Finally, cell 6 provides an example of multilateral sector-specific accords such as the Information Technology Agreement (ITA), negotiated in 1996, and the Basic Telecom Agreement (BTA) and Financial Services Agreement (FSA) a year later. ${ }^{5}$

The second row focuses on multiproduct efforts. Cell 7 refers to unilateral liberalization or restriction, and includes such actions as the British phase of liberalization in the 1850s or the 1930 Smoot-Hawley tariff in the United States. In cell 8, the Cobden-Chevallier Treaty of 1860 and subsequent bilateral agreements in Europe fit the category of geographically concentrated accords. In cell 9, we have cases of geographically dispersed bilateral agreements. Examples include the US-Israel free trade agreement (with the EC having a similar accord, and ones with Mexico and other countries as well). On a minilateral basis, ${ }^{6}$ cell 10 focuses on geographically focused minilateral agreements, accords that have traditionally been referred to as 'regionalism'. As should be clear from the table, however, cells 2, 4, and 8 are also forms of 'regionalism', although theoretically they may have quite different politicaleconomic implications. Here, European states have leaders with agreements such as the Zollverein, EC, European Free Trade Association (EFTA) and the European Economic Area (EEA). Cell 11 points to such accords as the Lomé Agreement, EC-Mercosur, and ASEM accords, all of which span regions, but which are not always a grouping that links specific regional arrangements together. These increasingly popular accords, which can be referred to as 'transregional' agreements if they link countries across two regions or 'inter-regional' agreements if they formally link free trade areas or customs unions, are of key theoretical and policy importance in understanding the likely evolution of the trading system. ${ }^{7}$ Finally, cell 12 refers to the case of global trading arrangements, namely multilateral, multiproduct arrangements such as the GATT and its successor organization, the WTO.

\section{II.2 Classifying monetary arrangements}

To offset trade-distorting manipulations of exchange rates, European governments have often committed to arrangements to manage exchange rates. To highlight the variety of these commitments, and their respective influence, we use a simple categorization with variation along two dimensions: (1) the number of parties involved; and (2) the type of exchange rate system that states commit to. Regarding the former, we follow the same distinction as for the case of trading arrangements - unilateral, bilateral, minilateral and multilateral. For the latter, we use the commonly used threefold distinction of hard peg, soft peg, and floating. ${ }^{8}$ Hard pegs refer to situations in which governments agree to forgo any independent exchange rate policy. They may adopt an external currency as legal tender - dollarization or euroization; they may rigidly and explicitly peg to an external currency through a currency board; or they may form any of two 
forms of monetary alliances - exchange rate unions and monetary unions (Cohen 1998). In contrast, soft pegs are less restrictive arrangements, leaving governments some room for unilateral changes. The menu of options is wide, including notably fixed-but-adjustable parities, crawling pegs, implicit pegs, and large or fuzzy bands (Wyplosz 2001b). Floating includes the benchmark case where governments preserve autonomy in exchange rate policy ('free floating' in Cooper's (1975) terms), but also the situation of managed floating in which governments intervene in the market at their own discretion.

Combining the two dimensions of variations yields 12 different categories of commitment, as illustrated with concrete examples in Table 6.2.

Before we briefly discuss these examples, it is important to note that our categorization does not explicitly address the question of the specific rules and procedures (such as margins of fluctuations, intervention requirements, collective reaction provisions, monitoring and enforcement of pegs) that go along with the various commitments. ${ }^{9}$ We might expect harder pegs with large number of actors to require more elaborate rules and procedures but there is much variation inside each of our 12 categories - something we carefully consider below in Section IV. Table 6.2 does not aim to be exhaustive, and does not list the solutions used by all countries at any time. In particular, it gives little attention to cells 5 and 9, where one can produce long lists of examples across time.

Row 1 of Table 6.2 indicates that European countries have a long experience with hard pegs. The first attempts were designed at the minilateral level (cell 3). In 1865, Belgium, France, Italy and Switzerland formed the Latin Monetary Union (LMU) that sought to standardize existing gold and silver coinages across the union and therefore to freeze mutual currency values. The LMU made each union member's money legal tender throughout the union (Cohen 1998). Another instance of an exchange rate union was the Scandinavian Monetary Union (SMU). Formed in 1873 by Sweden and Denmark, with Norway joining in 1875, the SMU established one uniform unit of account, the krone, based on gold. Like the LMU, each member's money circulated as legal tender throughout the union (Cohen 1998).

Minilateralism then gave way to an arrangement that would eventually govern world transactions - the Gold Standard. Whereas there is no question that the Gold Standard was a hard peg, one can debate whether it was a collective 'orchestrated' system (cell 3 or 4) or a collection of purely individual commitments on a common metallic anchor, gold (cell 1). For reasons that we discuss in Section IV below, one could consider that for major European countries, including Britain, France, Germany and Russia, the Gold Standard was a minilateral institution (cell 3), a kind of 'European Gold Standard' (Flandreau, Le Cacheux and Zumer 1998). For other countries, notably those at 

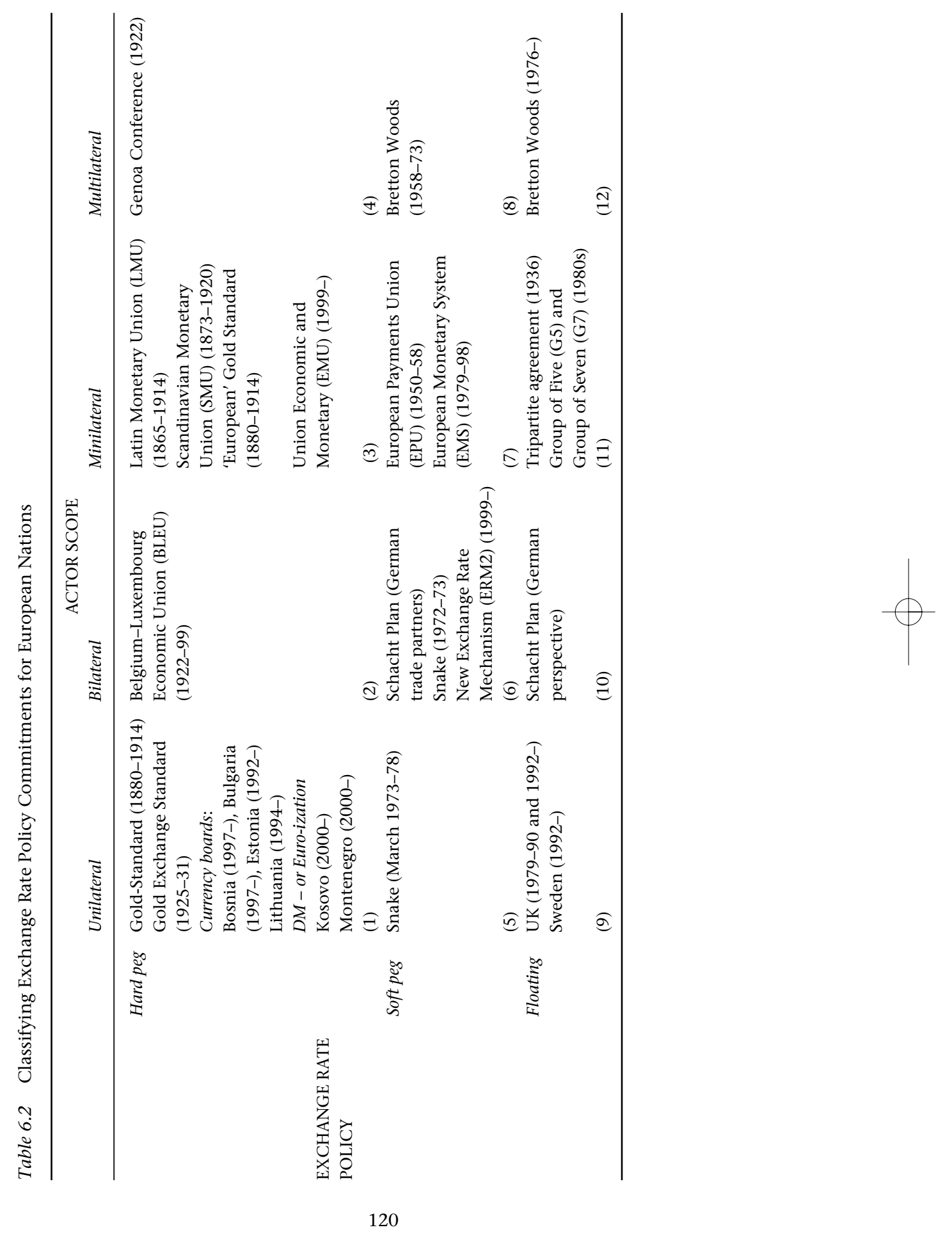
the periphery in North and Latin America, the Gold Standard was simply a unilateral hard peg (cell 1).

After the demise of the Gold Standard during the First World War, Europeans tried to relaunch it in a truly multilateral form. When these attempts failed, countries went back to gold on an individual basis. They formed what is generally labelled the Gold Exchange Standard, where there were few rules of the game, indicating a unilateral hard peg choice (cell 1). Meanwhile, the hard peg in Europe also followed a bilateral road, with the creation of the Belgium-Luxembourg Economic Union (BLEU) in 1922. BLEU was formally an exchange rate union, but given the asymmetry in the size of the members it quickly became a hierarchical arrangement with one currency pegged in a kind of currency board arrangement to the other. More recently, hard pegs have attracted much publicity, both at the minilateral level, with the advent of Economic and Monetary Union (EMU), and at the unilateral level, with currency boards and euroization in Central and Eastern Europe. Estonia, Bulgaria and Bosnia-Herzegovina have set up currency boards linking national currencies to the deutsche mark (DM) and now the euro, while Lithuania has preferred a peg to the dollar. Kosovo and Montenegro went even one step further and in late 2000 adopted the deutsche mark and now the euro as legal tender.

Turning to soft pegs, Europe has also been a rich laboratory of experiences. When the Bretton Woods (BW) arrangement quickly proved unable to address the problem of the return to convertibility in post-Second World War Europe, in 1950 European nations and the United States set up the European Payments Union (EPU). The EPU was a multilateral clearing system under the supervision of the Bank for International Settlements (BIS) and within the trade liberalization framework of the Organization of European Economic Cooperation (OEEC). Given that members could not use monetary policy to influence trade but had access to credits in case of deficits, the EPU could be categorized as a minilateral soft peg (cell 7). Twenty years later, after the breakdown of the BW system, Europeans began to redesign their minilateral soft peg. The first attempt, 'the Snake', aimed to stabilize bilateral parities among EC members without any collective support for the individual bilateral parities, which would place it in cell 6. In practice, the Snake quickly turned out to be a DM zone (Tsoukalis 1993) with Belgium, Denmark, the Netherlands, Norway and Sweden pegging unilaterally to a floating German mark (Heller 1978). The next attempt, the European Monetary System (EMS), was developed at the minilateral level. This arrangement sought to limit margins of fluctuations for bilateral exchange rates, with the collective provision of extensive short-term financing facilities to help members defend establish parities. The most recent soft peg is the new exchange rate mechanism (ERM2) embodied in the Amsterdam Treaty of the European Union that will link those EC members that are part of EMU to those that remain outside of it. The mechanism follows a hub and spoke pattern with 
bilateral parities set between all EMU members and each individual non-EMU member (cell 8).

Floating arrangements have been less frequent in Europe, with the exception of the interwar period. From 1920 to 1925, there was almost a free float. Later, following the disintegration of the Gold Exchange Standard, came the heyday of managed floating. At the bilateral level, Germany under the Schacht Plan designed a system of bilateral exchange clearing arrangements with its key trade partners. Given the tailored nature of these arrangements, we classify them as between soft bilateral pegs (from the perspective of Germany's trading partners that had to accept Germany's conditions) and bilateral floating solutions (from the German perspective). Britain organized economically around its empire, thus building a kind of minilateral response to international monetary problems (cell 7). Floating has never come back to such an extent in Europe. Although Europeans have been part of the stable system of exchange rates managed by the IMF since the mid-1970s (cell 12), they have for the most part been part of soft or hard pegs as discussed above. Notable exceptions have been the UK as well as Sweden after 1992 (cell 9).

\section{Trade: European contributions}

To examine Europe's leadership in designing novel forms of trade management, it is useful to consider the trajectory of European arrangements in two parts: from the 1840s to the 1930s, and from the 1940s to the present. This division allows us to systematically focus on some key institutional arrangements in each of these time periods with an eye toward their evolution. The Second World War provides a ready dividing line because the creation of the GATT marked a crucial shift in the trading system with the innovation of the first globally based trading regime. It also marked a shift away from the era of protection that sharply exacerbated the depression of the 1930s and which brought an end to the significant liberalization of the nineteenth century and early part of the twentieth century.

\section{III.1 The 1840s to 1930s: From unilateral liberalism to transnational protectionism}

The path of trade liberalization in the late nineteenth and early twentieth centuries was marked by a variety of agreements of different forms. In brief summary, the trajectory, based on the categories in Table 6.1 above, includes movement from cell 1 with unilateral sectoral liberalization by the British, and some unilateral broader scale liberalization (cell 7) to the bilateral Cobden-Chevallier Treaty in 1860 (cell 8). This agreement helped set broader liberalization in motion through additional geographically specific and dispersed agreements (cell 9). Even broader liberalization, albeit on a regional basis, was 
taking place about this time with the Zollverein (cell 10), which expanded from a set of bilateral agreements (cell 8). Soon thereafter, an inward turn in trade was marked by a move toward unilateral protection by several countries after the 1873 depression (cell 7). A second move toward protection came after another spate of liberalization in the late 1800s and early 1900s. In this case, the protectionism by the colonial countries took the form of an inward turn to their colonies, as with the transregionalism of the 1932 British Imperial Preference system (cell 11). Nearly simultaneously, the United States instituted the Smoot-Hawley tariff, the Germans created a set of bilateral agreements with the Schacht Plan, and many states concluded dispersed and concentrated bilateral agreements in the mid-1930s.

A more detailed view of this trajectory reveals some of the nuance omitted from the sketch of the broader trends. ${ }^{10}$ We begin with Britain's change of trade policy in the early 1840s. Its unilateral liberalization of trade in this decade was marked by the 1848 abolition of the Corn Laws and continued more broadly in the 1850 s. ${ }^{11}$ Trade policy was set according to the national political agenda, leaving others to determine their own liberalization efforts. Britain adopted a general policy of non-discrimination; in fact, trade treaties came to be viewed even as dangerous and disreputable.

During the decade following the repeal of the Corn Laws, few countries followed the British example. A significant systemic shift in policy only came about with the Anglo-French commercial treaty of 1860, which ushered in a period of generally free trade that ended only with the First World War. Under the terms of the treaty, France was obligated to abolish all prohibitions on goods and reduce specific duties to a maximum of 30 per cent ad valorem; most rates were set between 10 and 15 per cent (Bairoch 1989). Britain in turn reduced the number of tariffs from 419 to 48 and lowered the wine tariff. The treaty was subject to renewal after 10 years and could by terminated by either party with a year's notice. The inclusion of a most favoured nation (MFN) clause meant that any tariff concessions vis-à-vis third parties would automatically be extended to the other signatory party without need for renegotiations.

This commercial treaty had systemic implications for the rest of Europe. It launched a general movement toward freer trade as countries attempted to counter the trade diversion that was triggered by this bilateral treaty between the largest economies, and by the subsequent one (1862, effective in 1865) between France and the Zollverein. ${ }^{12}$ From this perspective, one can argue that a single bilateral treaty between France and Britain led to de facto multilateral agreement among most European states (Irwin 1993). Tariffs in this virtual multilateral agreement were mostly between 8 and 15 per cent, with a maximum of 25 per cent. At the start of 1908 Britain had MFN agreements with 46 countries, Germany with 30, and France with more than 20. Attempts were made to bring the colonies into the MFN system as well. 
What sets this system apart from later arrangements such as the GATT is the fact that this system arose more or less spontaneously and that it was more of a non-system than a formal arrangement. Commitment was therefore quite limited. The key anchor was the MFN principle. ${ }^{13}$ This principle was unexceptional and unconditional, meaning it was applied to all countries with which such an agreement was signed - and not only to those explicitly mentioned in any treaty, as had been the earlier practice. Unconditional meant that the lowest tariff was automatically applied to all without reciprocal concessions.

Although countries continued with the MFN principle, conflicts became more frequent after the late 1870s, and some countries began to turn inward. ${ }^{14}$ The main explanation for this change in trade policy toward a more restrictive course with rising tariff rates has been the decline in agricultural prices in the late 1860s and into the 1870 s. ${ }^{15}$ This shift in trade policy was exacerbated by the expiration in the 1890s of many of the earlier free trade treaties. ${ }^{16}$ Of the 53 treaties in force in 1889, 27 elapsed in 1892 and another 21 in 1895 (Bairoch 1989). Renewal of these treaties proved difficult as protectionist pressures increased and tariff wars began to erupt. These were generally triggered when one country rejected an agreement to implement higher tariffs. Such conflicts erupted between France and Italy in 1888-89, Germany and Russia in 1892-94, and France and Switzerland in 1892-95. The threat - and fact - of retaliation was no longer enough to ensure a low-tariff equilibrium among nations.

In assessing the period until the First World War, one might conclude that the main achievement of the period was the institution of MFN status - an innovative non-discriminatory trade policy in marked contrast to earlier practice in Europe. This is undoubtedly a major achievement. But in the absence of an international regime, the system of bilateral treaties failed to deliver a binding mechanism that could avoid a shift back to a more protectionist policy in times of crisis. There was no mechanism that could avoid the backlash after 1880, nor the more severe problems that arose after 1918.

The First World War changed the trading system profoundly. Tariff barriers, prohibitions, quantitative restrictions and exchange controls appeared quickly all over Europe to protect industries and to secure foreign exchange for state purposes. One reason for this deterioration is obviously the 1930s depression in the European economies. A second reason is the marked absence of any formal, multilateral attempt to return to a liberal trade policy, or to restore the MFN framework. Even though most wartime controls were phased out on a unilateral basis after the war had stopped, the process was very slow. In 1927, the League of Nations called for an end of prohibitions and other restrictions. Meanwhile, as countries removed their quantitative restrictions, tariffs took their place. Even Britain did not fully return to its prewar unilateral free trade policy.

Still, some attempts were made to return to a more liberal trading system. In 1927 the World Economic Conference called for a stabilization and subsequent 
reduction of trade barriers. Many governments expressed support for this view, and some countries gave up plans to increase their tariffs further. The United States had already readopted the unconditional MFN clause in 1922, and France did so as well when signing a treaty with Germany in 1927 . Thus, the prospects for the international trading system turned brighter in the late 1920s - but only for a fleeting moment.

In the summer of 1929, agricultural prices once again fell dramatically, prompting Germany, Italy, France and others to respond with strong tariff increases. The United States responded to this decline in June 1930 with the Smoot-Hawley tariff, which led to a round of retaliatory increases throughout Europe. In 1932, Britain formalized an internal turn to its colonies with the Ottawa Imperial Conference (Glickman 1947). This 'Imperial Preference' allowed British producers to secure market access and assured a supply of raw materials for British industry. This preferential trading arrangement marked a sharp turn away from the strong liberalizing movement following the Anglo-French commercial treaty of 1860 . Moreover, the accord did little to boost British industry. Together with the retaliation that followed the Smoot-Hawley tariff in the United States, the massive turn to bilateral trade agreements, and the competitive monetary devaluations of the 1930s, this movement marked a final end to the liberal trading order.

In contrast to the European leadership in liberalizing trade in the late nineteenth century, in the 1930s the United States began to assume greater responsibility within the international trade system. Having fostered a turn to protection by implementing the Smoot-Hawley tariffs, it subsequently tried to reverse this trend. At the Montevideo conference in 1933, the United States and other countries in the Americas promised to reduce trade barriers in the Western hemisphere. At home, the passage of the Reciprocal Trade Agreements Act of 1934 empowered the president to grant concessions of up to 50 per cent in bilateral trade negotiations. By 1939 the United States had signed 20 MFN treaties, covering some 60 per cent of its trade. Chief among them was a 1938 agreement with Britain that provided the nucleus for the postwar trading order and the Bretton Woods conference of 1944 that created a new international system.

As this discussion has shown, different countries played different roles in institutionalizing international trade between the mid-1800s and the 1930s. In the early to middle 1800s, regional integration efforts had been led by Germans in the form of the Zollverein. In the middle to late 1800s, other European countries, particularly Britain, were at the forefront of trade liberalization. The negotiation of bilateral agreements supplemented the initial unilateral British liberalization and led to systemic shifts toward an open international market. Although there was some retrenchment in the latter part of the 1800s, the open system continued - albeit in a more tenuous state - until the First World War. As we have seen, however, a liberal system based on bilateral agreements was 
quite fragile: as crises developed, countries began to shift their policies toward protection. Only Britain among the major countries retained truly liberal policies. By the 1930s, the British also turned inward toward their colonies, instituting a policy of Imperial Preference that created a transregional grouping that discouraged trade with outsiders. The open system was finally done in by the Depression, and the inward turn itself helped feed a deepening economic downward spiral. It was only with the leadership undertaken by the United States, a reluctant hegemon, that the system began to move toward openness; but the Second World War intervened in what would be a laboured process of post-Second World War liberalization.

III.2 The 1940s to 2000s: From multilateral liberalism to trade potpourri?

The multilateralism fostered by the GATT after 1947 (Table 6.1, cell 12), while reflecting a commitment to the institutionalization of liberalization, reflected at the same time the underlying dispute and dissensus within the United States that led to the stillborn International Trade Organization (ITO). This organization, slated to be the trade equivalent of Bretton Woods, was developed as an agreement that would have very broad issue coverage, an approach that generate controversy. Although the GATT served in lieu of the ITO in some respects, several of the disputes in discussions of the ITO were reflected in the assortment of trade measures that would follow, with many varieties being led by Europeans. Thus, despite the overwhelming success of the multilateral trade liberalization mechanism embodied in the GATT, competitors to the GATT continued to pop up and protectionist regression continued to assert itself.

Europeans continued to pursue regional and preferential approaches in trade, despite the GATT. The 1951 Economic Coal and Steel Community (cell 4) formally violated the GATT because of its focus on only two sectors, and its members sought a waiver of GATT obligations with US support. At the same time, Europeans enacted protectionist measures in specific sectors such as textiles and apparel in the 1950s - both on a unilateral (cell 1) and on a minilateral basis (cell 5). The expansion of the ECSC into the EC brought the European efforts into conformity with the GATT. As liberalization proceeded in the Community, nearby countries outside of the EC sought bilateral ties (cell 8), and inter-regional efforts were made to link the EC to EFTA. This movement accelerated with the end of the Cold War, as East Europeans sought market access to the EC. The EC tried to counter their pressure for full EC membership by creating a new regional institutional form, the European Economic Area (cell 10), that would link the European Free Trade Agreement to the EC. However, the effort made little headway as EFTA states sought membership in the EC instead and the Central and Eastern European countries were uninterested in EFTA. The Europeans also inherited longstanding preferential bilateral ties with colonies (cell 9) which were followed by the creation of minilateral transregional 
arrangements such as the Lomé Agreement, which linked former European colonies and later other developing states to Europe (cell 11).

More recently, the EC has supported the creation of sector-specific multilateral agreements such as the Information Technology Agreement, the Basic Telecoms Agreement and the Financial Services Agreement (cell 6). It has also begun to pursue bilateral agreements with distant countries such as Mexico (cell 9) and inter-regional agreements with Mercosur and a mixture of minilateral accords with Asian countries (cell 11). The result has been a potpourri of agreements that may not bode well for liberalization through the WTO.

Because the history of the ECSC and the EC are so well known, we find it more useful for purposes of this paper to focus on less well known or more controversial developments. In the 1950s, as trade liberalization through the GATT was proceeding, protectionist pressures began to build in both Europe and the United States. ${ }^{17}$ As a result, the United States negotiated Voluntary Export Restraints (VERs) with the Japanese, and the UK sought to restrict Japanese textiles as well as those from India, Pakistan and Hong Kong. With respect to Japan, the UK invoked Article 35 of the GATT, allowing it to withhold concessions from the Japanese and permitting it to continue restricting Japanese imports under the Anglo-Japanese Sterling Payments Agreement. The Commonwealth exporters proved to be a more difficult problem. Under Imperial Preference - renamed Commonwealth Preference to reflect decolonization former colonies had tariff-free access to the UK market, and vice versa. But the increasing imports from Commonwealth members India, Pakistan and Hong Kong, which benefited from restraints on the Japanese, proved to be a domestic British political problem. The solution to this problem was negotiated in the so-called 1959 Lancashire Pact, which called for India, Pakistan and Hong Kong to 'voluntarily' restrict their exports to the UK. This minilateral sectoral agreement proved to be instrumental in encouraging the US government to pursue a broader pact on textiles and apparel, as it too faced growing exports from Hong Kong and increasing political pressure from its domestic industry. The resulting international agreement, the 1961 and 1962 Short and Long Term Arrangements on Cotton Textiles, proved to be an innovation that would continue to be a thorn in negotiations between developed and developing countries. To this day, conflict over the phase out period for the successor Multifiber Arrangement (MFA) continues to haunt efforts to pursue a Millenium Round of negotiations under WTO auspices. ${ }^{18}$

With respect to bilateral and transregional links, some EC members such as France (and then later with its accession to the EC, the UK) had long-standing preferential trading arrangements with former colonies. The Treaty of Rome called for the continuation of such preferential agreements, and after their independence, 18 former colonies maintained their links to the EC through the first Yaoundé Convention of 1963 (renewed in 1969). This agreement was a 
transregional rather than an inter-regional agreement, as this grouping was a creation of the EC and not a free trade area or customs union in its own right. ${ }^{19}$

The Lomé Convention, a 1975 successor to the Yaoundé Convention, expanded the preferential arrangements to a large group of countries in Africa, the Caribbean and the Pacific (ACP), and governs European trade and financial relations between European countries and many of their former colonies. Created at the high-water mark of developing country unity in international trade and economic relations, the Lomé Convention (or Lomé I) institutionalized European support for and preferential treatment of ACP countries industries and exports. Lomé I was succeeded by Lomé II (1980), Lomé III (1985) and Lomé IV (1990), all of which extended the essential principles of the original agreement. However, Lomé IV expired in February 2000 with the Europeans and ACP countries having failed to agree to a Lomé $\mathrm{V}$. This failure is due in large part to the changing environment in global trade and finance - most notably the diminishing influence of ACP countries in the 1980s and 1990s, the accession of new members into the EC with different ties to developing countries, and the emergence of the WTO (Ravenhill 2001).

The WTO's strictures against preferential agreements have put tremendous pressure on the Europeans to dismantle the Lomé system, and the United States in particular has used the WTO's dispute mechanism to mandate an end to the EU's preferential treatment of $\mathrm{ACP}$ exports such as bananas, among others. If the WTO and globalism remain the effective level of trade arbitration, the EC may face major trade conflict with the United States and be tempted to jettison Lomé. Currently, it is considering a variety of alternatives that could lead to a combination of bilateral free trade agreements and five subregional Lomé agreements.

The European Union also has developed preferential trading arrangements with the Mediterranean countries. This policy began in the 1960s with loose concessionary trade agreements followed in the 1970s by an expansion of economic and financial cooperation. The Barcelona Declaration of 1995 codified the aims of the EC and Med12 countries (Algeria, Morocco, Tunisia, Egypt, Israel, Jordan, Lebanon, the Palestinian autonomous territories, Syria, Turkey, Cyprus and Malta), establishing 2010 as the goal for establishing a free trade area.

Finally, with respect to minilateralism, the EC has been more of a follower than a leader in the development of inter-regional agreements. The EC has long had ties to Asia, but the United States made the first move with its support for the Asia-Pacific Economic Cooperation (APEC) group in 1989 that had been promoted by Australia and Japan. Europe and ASEAN have a long history of formal, if limited, interregional ties: within the first few years of ASEAN's existence, the two established a permanent dialogue through both the Special Coordination Committee and the ASEAN-Brussels Committee. The latest development in the long-standing inter-regional dialogue between Europe and 
East Asian countries more generally has taken part with the Asia-Europe Meeting (ASEM), which originated from a proposal by Singapore Prime Minister Goh Chok Tong in 1994. In many respects, ASEM appears to be a response to the relative success of APEC at its 1993 Seattle meeting in setting free trade goals during the heated final negotiations of the Uruguay Round.

While the initial efforts within ASEM were made by the South East Asian states, Japan, China and South Korea have been an integral part of the Asian contingent, differentiating ASEM from the existing EU-ASEAN dialogue and thus combining inter-regionalism and transregionalism. Closer ASEAN-EC relations are largely contingent on the further institutionalization of ASEAN itself - an issue hotly contested in recent years among ASEAN members. Thus, it remains to be seen whether the Asian financial crisis and subsequent political undulations will reduce certain South East Asian countries' resistance to enhancing intra-ASEAN political coordination, and, if so, whether the EC will re-emphasize this transregional relationship in pursuit of a more robust ASEM.

With respect to ties to Latin America, the EC has also been concerned about US initiatives in the region, including the Enterprise for the Americas Initiative first discussed in the late 1980s and now reincarnated as the putative FTAA. Throughout the 1990s, Brazil, Argentina, Uruguay and Paraguay, each a member of Mercosur, followed programmes of fiscal discipline and economic liberalization. The economic expansion that these policies produced were mirrored - and reinforced - by expanding trade and investment ties with the European Union. In 1996 the EC replaced the United States - which has never been as dominant in Mercosur countries as in the rest of Latin America - for the first time as the principal source of foreign investment in Mercosur, and trade levels in most export sectors have multiplied over the decade. An EU-Mercosur inter-regional framework cooperation agreement was signed in December 1995, though its implementation has not been a simple matter owing in particular to conflicts over agriculture.

The Europeans have also been strongly behind the new trend in promoting sector-by-sector liberalization or 'open sectoralism', most notably the Information Technology Agreement (ITA) model, developed in $1996 .{ }^{20}$ The ITA covers over 90 per cent of the total trade in IT products among 69 participant countries. Similarly, the 1998 Global Agreement on Basic Telecommunications seeks to extend the same sectoral liberalization principle to trade in telecom products.

Although such agreements have been considered to be a promising avenue for trade liberalization, the effect over the long run may be the opposite. Politically, market opening along sectoral lines may reduce political support for multilateral, multisector negotiations that would benefit a significantly broader group of industries and consumers. By giving a few economically successful sectors the trade liberalization that they demand, such agreements can easily 
undermine the broad coalition for free trade. From an economic perspective, such agreements may also reduce economic efficiency. By liberalizing only specific, highly competitive sectors, open sectoral trade agreements may lead to incentives to invest in or discourage exit from the least efficient areas of the economy. It is, of course, difficult to prove that WTO liberalization would proceed more smoothly without such open sectoral agreements. But the concrete realization of the risk that open sectoral liberalization poses to global liberalization has become evident in the surprisingly weak lobbying effort and conservative agenda-setting priorities of US information technology and telecommunications industries for new round of the WTO. It appears that these sectors have come to rely on extant sectoral agreements and bilateral pressures to open key emerging markets, most notably China, and have lost interest in global institutions.

In summary, Europe's role in promoting liberal trade in the post-Second World War era is decidedly mixed. The creation of the EC has been an important regional liberalizing development, and it has actively participated in the GATT/WTO efforts to reduce trade barriers at the global level. But at the same time, European states have actively protected a number of sectors including textile and agriculture, largely to the detriment of developing countries. Moreover, the creation of the EC also led to a series of preferential agreements that reflect long-standing colonial arrangements from a previous era. While some of these such as Lomé have come under fire and are likely to be eliminated, the trend toward bilateral, transregional, and inter-regional arrangements have a great potential to distort trade by creating entrenched interests in such accords and a diminished interest in global liberalization. In addition, European support of the 'open sectoral' approach to liberalization in information technology, telecoms and other sectors also may similarly undermine efforts to promote broad-scale liberalization.

\section{Money: European contributions}

Due to historical circumstances, Europe was the cradle of the management of international monetary relations. The advent of the Gold Standard was a major breakthrough in world economic history. After the First World War, however, European influence in designing monetary arrangements gradually diminished. The attempts by Europeans to launch a new multilateral system that would draw upon the success of its predecessor ultimately failed, putting into question the relevance of hard pegs using gold as an anchor. The next major effort was made by the United States and Britain, and led to the creation of a new form of peg that was softer and multilateral - the Bretton Woods system. European solutions to their economic interdependence resurfaced once the BW system began to founder in the early 1970s. Instead of following the US road toward floating rates, members of the European Community started designing new pegging 
arrangements, initially with limited results but gradually with more impact on intra-European trade, and ultimately leading to the pathbreaking EMU.

To trace the roots of European monetary efforts, this section briefly discusses the strength and weaknesses of the Gold Standard as a monetary arrangement, and then turns in more detail to the evolution of European designs after the end of fixity under the BW system. We pay particular attention to the link between institutions and the nature of the cooperation problem, which allows us to discuss potential influence of current European solutions on the rest of the world.

\section{1 The Gold Standard: Institutional features and influence}

Britain was the only country on gold during most of the nineteenth century, with most other countries remaining on silver or a bimetallic standard. From the beginning of the 1870s, however, countries began to switch individually to a single gold standard. ${ }^{21}$ Participation in the Gold Standard regime only required three main rules: (i) convertibility between domestic money and gold at a fixed price; (ii) freedom for private citizens to import and export gold; and (iii) some rule relating the domestic money supply to the country's gold stock. ${ }^{22}$

With these features, gold flows would help restore trade imbalances, through the so-called 'price-specie flow model' of David Hume. ${ }^{23}$ In practice, however, gold flows never reached the expected levels (Eichengreen 1996) because central banks intervened to speed up the adjustment process. They used the discount rate to offset gold shipments, which raised the question of the responsibility for the common level of discount rates. The system remained stable at reasonable levels of discount rate due to a kind of follow-the-leader convention with the Bank of England as conductor of the orchestra (Eichengreen 1987). Stability was also enhanced by a kind of international solidarity (Eichengreen 1996), or set of 'implicit rules' (McKinnon 1993), that pushed central banks to help each other in case of temporary threats to convertibility, as in the case of the Bank of England during the Baring crisis in 1890.

There is clear evidence that the system imposed considerable restraint on the behaviour of countries both at the European core and at the periphery (Bordo and Rockoff 1996). Yet stability, in terms of compliance with the rules of the system, was higher at the centre. Here, there was some mutual help among central banks and national treasuries - in contrast to the periphery, where the absence of solidarity either from the centre or from neighbours pushed governments to go on and off gold depending on domestic political imperatives. In this sense, there was a small hard core of countries organized in a kind of minilateral hard peg system that has been termed the 'European Gold Standard' (Flandreau, Le Cacheux and Zumer 1998), and a broader, softer periphery made of countries that unilaterally pegged on to gold. The two parts contributed to 
the maintenance of the whole system, with Britain at its centre, through a mix of trade and capital flows.

The outbreak of the First World War proved a fatal shock for the Gold Standard. Convertibility was either suspended officially or citizens were asked to not convert domestic currency into gold, appealing to patriotism. When the war ended, persistent inflation ruled out a return to convertibility at old rates. Countries instead opted for freely floating exchange rates - with the notable exception of the United States, where inflation had been relatively moderate and gold reserves were abundant.

The 1920s were a period of persistent and ultimately unsuccessful attempts to return to the Gold Standard, which was seen as a desirable goal by almost all countries - in particular European ones. ${ }^{24}$ Governments did not consider changing the system except to use foreign currencies as reserves to cope with the problem of declining production of gold. This change had important consequences that would have required enduring cooperation among countries. Changing to a system of foreign currency reserves was conditional on other countries adopting the same policy (the new arrangement would have belonged to cell 4 in Table 6.2). A unilateral change of the backing for the domestic currency raised the danger of speculation against one's own currency if others remained on gold reserves.

Several conferences during the 1920s addressed this issue, with the most important being the 1922 Genoa conference. The aim was to negotiate an international convention that allowed countries to hold unlimited amounts of foreign currency reserves. Another theme of the conference was cooperation among central banks (Eichengreen 1996). They were to abstain from manipulating currency values and, most importantly, from an attempt to increase domestic gold reserves at the expenses of other countries. If all increased interest rates to attract gold, none could succeed but all would depress production and employment in a prisoners' dilemma-like situation. None of these aims were achieved, in particular due to US unwillingness to participate in any cooperative scheme.

Faced with this failure, European governments essentially went back to the old system in an uncoordinated way. The immediate result was that each government decided independently on the new gold parity, thereby straining the system. With sharp initial asymmetry, finding an equilibrium between those in deficit and those in surplus quickly proved elusive. Simultaneously, the virtuous circle of confidence between markets and governments that sustained the pre-First World War system never re-emerged after the war. Social and political changes at the domestic level cast doubt on policy-makers' commitment to defend convertibility first - rather than to address domestic problems (Eichengreen 1992; Simmons 1994). Although there were differences between countries concerning the relative weight that was put on exchange 
rate stability, all countries shared the willingness not to surrender all social and economic policies to the requirements of being on gold. Hence, devaluations became a real and present possibility and investors became accordingly nervous and cautious.

Under such conditions, the depression that hit the United States and subsequently the rest of the world in the late 1920s was too strong a shock for the system to survive. Germany and Britain suspended convertibility in the summer of 1931, with two dozen countries following their move by 1932 (Eichengreen 1996). Monetary arrangements for those that had suspended gold convertibility strictly followed the trade flag, with Germany organizing exchange clearing systems under the Schacht Plan (Momtchiloff 1954) and Britain using the pound inside the Imperial Preference scheme. These practices further eroded the position of countries still on gold - notably the United States, which ultimately suspended gold convertibility in 1933. By 1936, the return to the floating situation of the early 1920s was complete (Eichengreen 1996). This was less a free float, as it had been before 1925, than a managed float whereby countries actively influenced their currency values.

The desire to avoid the trade-inhibiting consequences of unilateral manipulations triggered the design of a new international system. This design, under the leadership of the United States, led to the first coherent soft peg, the Bretton Woods system. It differed from the classic Gold Standard in many ways. ${ }^{25}$ The United States was the only country that fixed its currency against gold. Other countries declared (adjustable) parities against the US dollar or gold, and kept currency reserves in terms of gold or dollars. Members would get financial help in case of balance of payments difficulties through the creation of a financial pool. As a further step to ease compliance with parities, members built up controls over capital movements.

In sum, Europe pioneered minilateral systems of hard pegs but failed to adapt them to changing political and economic conditions at both the domestic and international level. A less asymmetric relationship of interdependence between Europe and the rest of the world, coupled with more open domestic polities, made a return to the Gold Standard impossible. To be successful, a new system was needed with formal rules and procedures. Yet the Europeans failed to produce such a system. One reason for this failure was that they lacked the power to supply such a system on their own, with London being challenged by New York. But, they also failed on the cognitive dimension, with a strong intellectual desire to mimic the erstwhile Gold Standard. There was little consideration given to the possibility of a softer peg, with means to make adjustment less costly. In particular, financing facilities were not created and there was no discussion of the relevance of full mobility of capital under a gold standard. ${ }^{26}$ 


\section{IV.2 From soft snake to hard EMU}

Europe went back to the drawing board of monetary arrangements in the late 1960s when the Bretton Woods system began to break down. The initiative came from the members of the European Community that wished to preserve intra-European exchange rate stability. Following an impetus from the Commission, in 1969 member states set up a committee with a mandate to review the status quo of monetary cooperation in Europe and to propose a blueprint for the transition to a common currency. The Werner committee, named after its chairman, the Prime Minister of Luxembourg Pierre Werner, proposed the creation of monetary union in Europe through a three-stage process. Specifically, it called for the irreversible fixing of exchange rates, the liberalization of capital markets, and the establishment of a common European central bank to manage common monetary policy (Kruse 1980; Ludlow 1982).

This ambitious proposal failed to survive the US decision to close the gold window in August 1971. What remained of the plan was the very first stage, a scheme called the Snake in the (dollar) tunnel, to restrict intra-European bilateral fluctuations to plus-or-minus 2.25 per cent. The scheme included the provision of short-term and very-short financing facilities to help members sustain established parities, and would be monitored by a European Monetary Cooperation Fund (EMCF) (Gros and Thygesen 1992). But the US decision to float the dollar in March 1973 and the first oil shock quickly showed that the Snake was too soft an arrangement to bring exchange rate stability in Western Europe. There was no binding rule to collectively defend bilateral parities, which proved unworkable for those countries in deficit. Under these conditions, the Snake was quickly reduced to a kind of hub and spoke system around the German mark that included countries with strong trade ties with Germany and that wanted to import Germany's success in controlling inflation (Heller 1978; Tsoukalis 1993).

Drawing upon the failure of the Snake and reacting to the increasing intraEuropean strains coming from the vagaries of the dollar, France, Germany and the United Kingdom designed a new arrangement in the late 1970s, the EMS. Its main element was the European Exchange Rate Mechanism (ERM), a grid of bilateral parities that allowed for a fluctuation of plus-or-minus 2.25 per cent (Gros and Thygesen 1992; Ludlow 1982). The system included short- and midterm credit lines to support interventions and to deal with balance of payments problems. Unlike the IMF, which mades loans from its funds derived from member states, the provision for credit in the EMS was on a bilateral basis. The EMS also created a common unit of account, the European Currency Unit (ECU).

In contrast to the Snake, the EMS imposed concrete obligations on member states. They had to intervene in markets to support exchange rates, and they had to provide financial facilities to those who engaged in costly efforts of intervention. Also in contrast to the Snake, there was explicitly a long-term 
perspective behind the EMS. Germany and France, in particular, made it clear that the new system not only aimed at the stabilization of the exchange rates but also that it should also lead to deeper cooperation in monetary matters (Kruse 1980; Ludlow 1982).

The EMS brought stability to European exchange rates. The standard deviation of effective exchange rates of ERM members was on average half of that the rest of the world during the period 1975-99 (Wyplosz 2001a). Yet, the system came under stress in the mid-1980s, mostly due to the mismatch between intra-zone restrictions on capital movements and global financial integration. Once the liberalization of capital movements was accepted with the Single European Act in 1986, it became clear that the EMS needed to be redesigned. The demand came first from those countries that had to do most of the interventions, the weak-currency countries, as opposed to the dominant-currency country, Germany. But the latter quickly followed suit and proposed the move toward Economic and Monetary Union (Dupont and Wolf 1998). After speedy preparatory work by a special committee, chaired by the President of the EC Commission, Jacques Delors, in December 1991, member states endorsed a plan to move toward a monetary union with a single currency by 1 January 1999.

Under the EMU, members have abandoned national currencies and transferred monetary policy to a supranational and independent 'central bank', the European System of Central Bank (ESCB), committed to the prime objective of price stability (Gros and Thygesen 1992; Kenen 1995). To ensure the smooth functioning of EMU, member states have also committed to restrictions (or restraint) in the use of budgetary policy through the so-called Stability and Growth Pact, which puts a 3 per cent limit on government deficits. They have also agreed to broader structural policies in labour, product and services markets through the development of the so-called reinforced economic policy coordination. ${ }^{27}$

EMU is clearly an exceptional arrangement - one without any historical equivalent. Yet this, per se, does not necessarily mean that Europe is back as a leader in institutional design. EMU may turn out to be a precursor but this may still take some time. EMU is the ultimate stage of a long experience of collective pegging, under different conditions of capital mobility, and was made possible thanks to its nesting in a large institutional framework that has helped build up mutual trust and confidence.

\section{Conclusion}

Europe has been a key player in the creation of institutional arrangements in international trade and money, both in the nineteenth and twentieth centuries. Yet its actions have had both positive and negative consequences for the liberalization of trade and the stability of the international monetary system. This 
paper has sought to analyse the variety of arrangements developed over the last two centuries through an innovative conceptual framework for understanding the institutional arrangements in these two issue areas. This approach allows us to also consider the interaction among different types of arrangements, and the prospects for the evolution of the trade and monetary systems.

In brief summary, the typology for trade and monetary arrangements focuses on three elements. For both the trade and monetary area, we consider the number of actors involved in the agreement (unilateral, bilateral, minilateral or multilateral) as well as whether the arrangements are geographically concentrated ('regional') or link states across long distances. With respect to the third element, we examine trade and monetary accords differently. For trade, we examine whether the coverage of products has been either narrow or broad in scope. Put differently, do trade arrangements address the whole host of products and services that might be traded, or only a few? In the monetary area, we focus on three possibilities: hard pegs, soft pegs, and floating. The combination of these elements allows us to create comprehensive typologies for classifying both trade and monetary arrangements (see Tables 6.1 and 6.2).

What do we see in terms of European contributions to the evolution of the trading and monetary systems? We divide the analysis of trade into two different eras: the mid-1800s to the Second World War; and the Second World War to the present. In the mid to late 1800s, following the repeal of the Corn Laws in 1846, the British took the lead in trade liberalization. Following negotiation of the pathbreaking bilateral Cobden-Chevallier Treaty in 1860, bilateral agreements supplemented the initial British move toward unilateral liberalization and led to systemic shifts toward an open international market. Although some countries turned toward protection in the latter part of the 1800s, the British maintained their policy of open trade and the system as a whole continued to remain relatively liberal. But, as we have argued, an open liberal system based on bilateral agreements remained fragile. As countries shifted their policies toward protection, there was no institutional mechanism to retard this trend. In fact, when the British turned inward toward their colonies in the 1930s, the open system came to an end and trade retaliation became the order of the day. Subsequently, Europeans had to rely on the leadership of the United States, a reluctant hegemon, to move the system toward openness - a move that would have to wait until after the Second World War.

In the post-Second World War period, Europe was a font of tremendous institutional innovation. It led the movement toward regional integration, a development that was often imitated in the 1960s - albeit one that rarely succeeded. But the creation of the EC also brought with it a more negative element for the liberal trading system: the formation of preferential trading arrangements. As the EC has evolved, it has continued to pursue such accords, first with developing countries through the Lomé Agreement, and then with 
Eastern European countries, the Mediterranean region, and others. More recently, the EC has actively taken up inter-regionalism - although in this case it has proved to be more of a follower than a leader behind the United States, which has pursued agreements with East Asia and Latin America through APEC and the FTAA respectively. However, the EC has also been an active leader and participant in the formation of bilateral agreements and sector-specific multilateral agreements such as the ITA and the Basic Telecom agreement.

What do these new forms of trade liberalization portend? Is liberalization, be it through any institutional mechanism, preferable to the pursuit of slow-going multilateral multisector negotiations? While the negotiation of bilateral and sector-specific agreements has intuitive appeal - especially to those exponents of the 'bicycle theory of trade' who believe that one must keep moving forward to maintain a liberal trading order - we believe that such arrangements can be detrimental from a political-economic standpoint. Through the creation of agreements that suit the interests of specific sectoral interests, the broader coalition that would support an open trading policy can be easily undermined, resulting in diminished interest in broad-scale negotiations. The result may be a strengthening of the political power of interests such as textiles and steel that are increasingly uncompetitive in the rich industrial countries. Bilateral agreements can be similarly corrosive. As a patchwork of agreements is created, 'less desirable' countries are left out, and competitive bilateralism may lead not to greater liberalism as it did for some time in the nineteenth century, but to the pursuit of political favouritism and the erosion of support for the WTO.

In money, the Europeans pioneered minilateral systems of hard pegs in the second half of the nineteenth century. Some of these systems still have influence more than a century later - especially in those countries in the periphery of a strong currency. After the First World War, European influence in designing monetary arrangements gradually diminished with its failure to launch a stable Gold Exchange Standard. The United States then took an active leading role and designed the first truly multilateral monetary system, the Bretton Woods system, anchored by the US dollar. But Europe did not follow the US lead for long. Once the dollar went off gold, the Europeans started to pursue their own options through the design of a series of arrangements that aimed to stabilize European exchange rates. The ultimate step in monetary cooperation has been the move toward an unprecedented monetary union - a develoment that clearly puts Europe in the forefront of currency management.

Our analysis of the European role in the monetary system shows the interplay of power and ideas. While Europe pioneered minilateral systems of hard pegs, it failed to adapt them to changing political and economic conditions. As other countries began to catch up economically with Europe, and as pressure to pursue more open domestic polities increased, a return to the Gold Standard became increasingly difficult. A more formalized international regime to counter the 
aggressive competitive devaluation of the 1930s was needed, but the Europeans could not produce such a system. From a political standpoint, the United States came to challenge British political and financial dominance. And from the standpoint of innovation, the Europeans failed to envision a new system that would go beyond the Gold Standard that might include a softer peg.

The most recent innovation in the monetary system, the EMU, looks to have significant promise and may be seen as attractive to those in other regions in the world who have been buffeted by the winds of unrestricted capital flows. Yet the EMU is not an easy arrangement to copy - particularly given its creation in the context of a long-standing regional integration effort. Moreover, the euro is a new phenomenon, and many countries, even in the European Union, do not appear fully convinced of its prospects.

For states in other regions, however, being a follower may have its advantages. Asian countries, through the Chang Mai initiative, have clearly indicated their interest in collective action to protect against the vagaries of markets. The Southern Cone in Latin America is still coping with the consequences of the forced devaluation of the Brazilian currency in 1999 and the Argentine devaluation of January 2002. These countries will be watching carefully whether there is life for a softer belt around the hard core of EMU. The new exchange rate mechanism (ERM2) linking those EC members inside the EMU with those outside of it would - if successful - be good news to those groupings that need to accommodate more heterogeneity, both politically and economically.

On a more general level, three conclusions emerge. First, Europe seems to have had a U-shape leadership in institutional design; this shape largely follows the trend in economic interdependence among European countries. Europe did not have much to offer in the interwar period due to political and military developments. Second, with respect to the development of solutions, Europeans have mostly focused on solving their particular problems and not as leaders for others. Put differently, Europe seems to have little desire to be an exporter of institutional designs. Third, building on this second observation, given the specific objective and context of European solutions, these blueprints will prove difficult to copy. Unless other regions reach comparable degrees of interdependence, they will not be interested or able to use European solutions. Yet there are growing signs that the time for these conditions to be fulfilled may not be so far away. Europeanization of the globe may turn out not to be a phenomenon of the past, but the wave of the future.

\section{Notes}

For comments and suggestions we are particularly indebted to Charles Wyplosz and Ed Fogarty. This paper draws on joint work between Cédric Dupont and Carsten Hefeker under the financial assistance of the Swiss National Science Foundation (grant 12-52815.97). 
1. We begin our analysis in the nineteenth century. For a discussion of earlier trends and developments, see Findlay (Chapter 2, this volume).

2. For the sake of convenience, we shall throughout the paper use the European Community (EC) as a generic title for the integration process from the Treaty of Rome to the current status. Historical accuracy would force us to distinguish between the European Communities, the European Economic Community, the European Community and the European Union.

3. This table was first developed in Aggarwal (2001).

4. For a good discussion of bilateral agreements, see Snyder (1940).

5. For a discussion and critique of these agreements, see Aggarwal (2001) and Aggarwal and Ravenhill (2001)

6. See Yarbrough and Yarbrough (1987) for a discussion of minilateralism.

7. See Aggarwal and Fogarty (2001) for a discussion of regionalism, transregionalism and inter-regionalism.

8. In a different vein, Cooper (1975) develops a typology of monetary regimes based on five 'roles' of exchange rates - fixed, adjustable parities, gliding parities, managed float, and free float - coupled with the reserve assets and the degree of market convertibility for capital movements.

9. For a discussion that focuses on the legalization processes, see Kohen (Chapter 4, this volume).

10. The discussion in this section draws on Dupont and Hefeker (2001). For a complement see $\mathrm{O}^{\prime}$ Rourke (Chapter 3, this volume).

11. On the abolition of the Corn Laws, see Schonhardt-Bailey (1996) and O'Rourke and Williamson (1999).

12. The Zollverein was itself an interesting innovation. Its nucleus was the customs union between Prussia and Hesse-Darmstadt in 1828. From then until its end in 1866, sixteen major states joined this nucleus to form the German Customs Union (Mattli 1999:112). Prussia was clearly the leader of the union with other members following, mainly because they wanted to get an access to its market (for more see Henderson 1958 and Mattli 1999).

13. See Lazer (1999) for an analysis of the effects of MFN.

14. See Gourevitch (1986) on responses to the 1873 depression.

15. See O'Rourke and Williamson (1999: Chapter 6), and O'Rourke (Chapter 3, this volume).

16. The extent of the shift in trade policy is a contested topic. For instance, Irwin (1993) argues that the shift was not very important. Tariff rates remained relatively low up to 1914, and some countries like Germany actually reversed their trade policy course after the 1880s. Bairoch (1989) on the contrary argues that there was a severe reversal, with several important countries returning gradually to 1800 tariff levels. Although the truth is probably in between these two positions, the dominant view is that significant shifts occurred.

17. See Aggarwal (1985) for a detailed discussion of textile restraints.

18. The Uruguay Round agreements called for the phase out of the MFA by 2005.

19. See Ravenhill (2001) for a discussion of Lomé since its inception.

20. This section draws heavily on Aggarwal (2001) and Aggarwal and Ravenhill (2001).

21. See Dupont and Hefeker (2001) for a discussion of the contending explanations for the switch to gold.

22. Eichengreen (1985). McKinnon (1993) lists six rules, three explicit ones that correspond to Eichengreen's three rules and three implicit ones that govern the behaviour of central banks and treasuries. For a more general discussion on the 
existence and effects of rules during the Gold Standard period, see Bordo and Schwartz (1984).

23. For a discussion of Hume's model and its application to the case of the Gold Standard, see Eichengreen (1996:25-30).

24. In Britain, the Cunliffe committee, in charge of drafting proposals for the postwar monetary system, did not consider any alternative to restoring the Gold Standard.

25. On the Bretton Woods system, see Eichengreen (1996) and James (1995).

26. The League of Nations actively encouraged the removal of all restrictions on capital mobility from 1925 onward (see Nurkse 1944). See Simmons (1994) for a discussion of national policies toward capital controls.

27. For a discussion of EMU in the context of global financial markets, see Steinherr (Chapter 7, this volume).

\section{References}

Aggarwal, V. K. (1985). Liberal Protectionism. Berkeley: University of California Press.

Aggarwal, V. K. (2001). 'Governance In International Trade: Changing Patterns of Sectoralism, Regionalism, and Globalism', in P. J. Simmons and C. de Jonge Oudraat (eds), Managing a Globalizing World: Lessons Learned Across Sectors. Washington, DC: The Carnegie Endowment for International Peace.

Aggarwal, V. K. and E. A. Fogarty (2001). 'Between Regionalism and Globalism: European Union Transregional Trade Strategies'. Paper presented at the conference, 'Between regionalism and globalism: European Union transregional trade strategies,' Institute of European Studies and Berkeley APEC Study Center (BASC), University of California, Berkeley, 28 September.

Aggarwal, V. K. and J. Ravenhill (2001). 'How Open Sectoral Agreements Undermine the WTO'. Asia-Pacific Issues 50 (February).

Bairoch, P. (1989). 'European Trade Policy, 1815-1914', in P. Mathias and S. Pollard (eds), The Cambridge Economic History of Europe (vol. 3). Cambridge: Cambridge University Press.

Bordo, M. and A. Schwartz (eds) (1984). A Retrospective on the Classical Gold Standard. Chicago: Chicago University Press.

Bordo, M. D. and B. Eichengreen (1998). 'The Rise and Fall of a Barbarous Relic: The Role of Gold in the International Monetary System'. NBER Working Paper no. 6436.

Bordo, M. and H. Rockoff (1996). 'The Gold Standard as a Good Housekeeping Seal of Approval'. Journal of Economic History 56(2): 389-428.

Cohen, B. J. (1998). The Geography of Money. Ithaca: Cornell University Press.

Cooper, R. N. (1975). 'Prolegomena to the Choice of an International Monetary System'. International Organization 29(1): 63-97.

Costigliola, F. C. (1977). 'Anglo-American Financial Rivalry in the 1920s'. The Journal of Economic History 37(4): 911-34.

Dupont, C. and C. Hefeker (2001). 'Integration Linkages: Between Trade-Offs and Spillovers'. Paper presented at the Fourth Pan-European IR conference, Canterbury, UK, 8-10 Sept.

Dupont, C. and D. Wolf (1998). 'Germany and EMU: A New Institution to Preserve an Old Good'. Center for German and European Studies Working Paper, no. 1.53.

Eichengreen, B. (1985). 'Editor's Introduction', in B. Eichengreen (ed.), The Gold Standard in Theory and History. New York: Methuen. 
Eichengreen, B. (1987). 'Conducting the International Orchestra: Bank of England Leadership under the Classical Gold Standard, 1880-1913'. Journal of International Money and Finance 6: 5-29.

Eichengreen, B. (1992). Golden Fetters. Oxford: Oxford University Press.

Eichengreen, B. (1996). Globalizing Capital: A Short History of the International Monetary System. Princeton: Princeton University Press.

Estevadeordal, A., B. Frantz, and A. M. Taylor (2001). 'The Rise and Fall of World Trade, 1870-1939'. IADB, USAID and UC Davis, ms.

Flandreau, M., J. Le Cacheux, and F. Zumer (1998). 'Stability without a Pact? Lessons from the European Gold Standard, 1880-1914'. Economic Policy (April): 117-62.

Friedman, M. (1990). 'The Crime of 1873'. Journal of Political Economy 98(6): 1159-94.

Glickman, D. L. (1947). 'The British Imperial Preference System'. The Quarterly Journal of Economics 61(3): 439-70.

Gourevitch, P. (1986). Politics in Hard Times. Ithaca: Cornell University Press.

Gros, D. and N. Thygesen (1992). European Monetary Integration: From the European Monetary System to European Monetary Union. London: Longmans.

Heller, H. R. (1978). 'Determinants of Exchange Rate Practices'. Journal of Money, Credit and Banking 10(3): 308-21.

Henderson, W. O. (1958). The Zollverein. Chicago: Quadrangle Books.

Hirschman, A. (1945). National Power and the Structure of Foreign Trade. Berkeley: University of California Press.

Irwin, D. (1993). 'Multilateral and Bilateral Trade Policies', in J. D. Melo and A. Panagariya (eds). New Dimensions in Regional Integration. Cambridge: Cambridge University Press.

James, H. (1995). International Monetary Cooperation since Bretton Woods. New York: Oxford University Press.

Kenen, P. B. (1995). Economic and Monetary Union in Europe: Moving Beyond Maastricht. Cambridge: Cambridge University Press.

Kruse, D. C. (1980). Monetary Integration in Western Europe: EMU, EMS and Beyond. London: Butterworths.

Lazer, D. (1999). 'The Free Trade Epidemic of the 1860s and Other Outbreaks of Economic Discrimination'. World Politics 51(4): 447-83.

Ludlow, P. (1982). The Making of the European Monetary System: A Case Study of the Politics of the European Community. London: Butterworth.

Mattli, W. (1999). The Logic of Regional Integration: Europe and Beyond. Cambridge: Cambridge University Press.

McKinnon, R. I. (1993). 'The Rules of the Game: International Money in International Perspective'. Journal of Economic Literature 31(1): 1-44.

Momtchiloff, N. I. (1954). 'Schachtian Mercantilism'. Journal of Industrial Economics 2(3): 165-73.

Nurkse, R. (1944). International Currency Experience. Geneva: League of Nations.

O'Rourke, K. H. and J. G. Williamson (1999). Globalization and History: The Evolution of a nineteenth Century Atlantic Economy. Cambridge: MIT Press.

Ravenhill, J. (2001). 'Back to the Nest? Europe's Relations with the African, Caribbean and Pacific Group of Countries'. Paper presented at the conference, 'Between regionalism and globalism: European Union transregional trade strategies', Institute of European Studies and Berkeley APEC Study Center (BASC), University of California, Berkeley, 28 September.

Schonhardt-Bailey, C. (ed.) (1996). Free Trade: The Repeal of the Corn Laws. Bristol: Thoemmes Press. 
142 Europe and Globalization

Simmons, B. A. (1994). Who Adjusts? Domestic Sources of Foreign Economic Policy during the Interwar Years. Princeton: Princeton University Press.

Snyder, R. C. (1940). 'The Most Favored Nation Clause and Recent Trade Practices'. Political Science Quarterly 55(1): 77-97.

Tsoukalis, L. (1993). The New European Economy. Oxford: Oxford University Press.

Verdier, D. (1994). Democracy and International Trade: Britain, France and the United States, 1860-1990. Princeton: Princeton University Press.

Wyplosz, C. (2001a). 'A Monetary Union in Asia? Some European Lessons'. Graduate Institute of International Studies, ms.

Wyplosz, C. (2001b). 'Regional Exchange Rate Arrangements: Some Lessons From Europe'. Graduate Institute of International Studies, ms.

Yarbrough, B. V. and R. M. Yarbrough (1987). 'Cooperation in the Liberalization of International Trade: After Hegemony, What?' International Organization 41(1): 1-26. 